Article

\title{
Application of Ultrasound-Assisted Extraction and Non-Thermal Plasma for Fucus virsoides and Cystoseira barbata Polysaccharides Pre-Treatment and Extraction
}

\author{
Ana Dobrinčić ${ }^{1, *(\mathbb{D})}$, Zoran Zorić ${ }^{1}\left(\mathbb{D}\right.$, Sandra Pedisić $^{1}\left(\mathbb{D}\right.$, Maja Repajić $^{1}$, Marin Roje $^{2}$, Zoran Herceg $^{1}$, \\ Rozelindra Čož-Rakovac ${ }^{2}$ and Verica Dragović-Uzelac ${ }^{1}$ (D)
}

Citation: Dobrinčić, A.; Zorić, Z.; Pedisić, S.; Repajić, M.; Roje, M.;

Herceg, Z.; Čož-Rakovac, R.;

Dragović-Uzelac, V. Application of Ultrasound-Assisted Extraction and Non-Thermal Plasma for Fucus virsoides and Cystoseira barbata

Polysaccharides Pre-Treatment and Extraction. Processes 2022, 10, 433 https://doi.org/10.3390/pr10020433

Academic Editor: Maria Angela

A. Meireles

Received: 31 January 2022

Accepted: 18 February 2022

Published: 21 February 2022

Publisher's Note: MDPI stays neutral with regard to jurisdictional claims in published maps and institutional affiliations.

Copyright: (C) 2022 by the authors. Licensee MDPI, Basel, Switzerland. This article is an open access article distributed under the terms and conditions of the Creative Commons Attribution (CC BY) license (https:// creativecommons.org/licenses/by/ $4.0 /)$.
1 Faculty of Food Technology \& Biotechnology, University of Zagreb, Pierottijeva 6, 10 000 Zagreb, Croatia; zzoric@pbf.hr (Z.Z.); spedisic@pbf.hr (S.P.); mrepajic@pbf.hr (M.R.); zherceg@pbf.hr (Z.H.); vdragov@pbf.hr (V.D.-U.)

2 Ruđer Bošković Institute, Biljenička cesta, 10000 Zagreb, Croatia; marin.roje@irb.hr (M.R.); rozelindra.coz-rakovac@irb.hr (R.Č.-R.)

* Correspondence: adobrincic@pbf.hr

\begin{abstract}
Brown algae Fucus virsoides and Cystoseira barbata are an abundant source of sulfated polysaccharide fucoidan, which has shown a wide range of biological activities. These activities are significantly dependent on the fucoidan chemical composition, which is closely linked with the applied extraction technique and process parameters. In order to overcome the drawbacks of lengthy conventional extraction (CE), advanced extraction techniques, such as ultrasound-assisted extraction (UAE) and non-thermal plasma (NTP), were applied. Furthermore, this study also investigated the efficiency of different solvents as well as UAE and NTP as $5 \mathrm{~min}$ pre-treatments prior to CE as a more effective course of cell wall breakage and, consequently, a higher polysaccharide yield (\%PS). Apart from \%PS, the effect of this procedure on the chemical composition and antioxidant capacity of the extracted polysaccharides was also monitored. When comparing the extraction solvent, the application of $0.1 \mathrm{M} \mathrm{H}_{2} \mathrm{SO}_{4}$, instead of $\mathrm{H}_{2} \mathrm{O}$, resulted in a three-fold higher \%PS, a higher sulfate group, and a lower fucose content. Application of CE resulted in higher \%PS, uronic acids, and fucose content as well as oxygen radical absorbance capacity (ORAC) and DPPH values, while the average molecular weight $\left(\mathrm{M}_{\mathrm{W}}\right)$, sulfate group, and glucose content were lower during $\mathrm{CE}$ when compared to 30 min of UAE and NTP treatment. Application of UAE and NTP as 5 min pre-treatments decreased fucose content, while \%PS and sulfate content were similar to values obtained when using CE.
\end{abstract}

Keywords: ultrasound-assisted extraction; non-thermal plasma; polysaccharides; extraction; brown algae; advanced extraction techniques; fucoidan; antioxidant capacity

\section{Introduction}

Seaweeds or marine macroalgae are an excellent source of nutrients and bioactive molecules with a broad range of applications in the food, pharmaceutical, cosmetics, and textile industries. Among the nutrients and bioactive molecules present in macroalgae (polysaccharides, proteins, peptides, amino acids, polyphenols, pigments, vitamins, minerals, etc.), polysaccharides (PS) are the most prominent with respect to possible commercial application. According to the latest worldwide statistics on aquaculture compiled by the FAO in 2018, total production of aquatic algae was 32.4 million tons with a total sale value of USD 13.3 billion [1].

Fucus virsoides is an endemic species in the Adriatic Sea, and it is the only species of the Fucus genus to occur in the Adriatic Sea [2]. It has a perennial flat dark brown thallus that is dichotomously branched, flattened, and with a distinct midrib [3]. Cystoseira barbata is an endemic species of the Mediterranean Sea, growing mostly in the coastal area of the 
northern Adriatic and most abundantly during April and May [4]. It is a perennial, large, strongly branched, flexible, brown alga that can grow up to $2 \mathrm{~m}$.

F. virsoides and C. barbata are potentially a good source of PS-fucoidan, laminarin, and alginate. Fucoidan is sulfated PS with high fucose content interconnected by $\alpha-(1,3)$ glycoside bonds or by alternating $\alpha-(1,3)$ and $\alpha-(1,4)$ bonds (and very rarely $\alpha-(1,2)$ bonds). Apart from fucose, it contains lower amounts of other monosaccharides including glucose, galactose, mannose, xylose, rhamnose, and uronic acids [2]. It is found in the fibrillar tissue of the cell wall and the intercellular space of brown algae, and it has been established that it possesses a wide range of positive effects such as antioxidant, anti-inflammatory, and antitumor [5-7], which give it great potential for use in a wide range of functional food, cosmeceutical, and pharmaceutical products [8]. Biological functions of fucoidan are closely correlated with its physicochemical properties [9], namely, sulfate group content, sulfate group position, molecular weight, types and ratios of constituent monosaccharides, and features of glycosidic bonds. However, these physicochemical properties are influenced by algal species, location, harvesting season [10], extraction techniques, and different extraction conditions (e.g., time, temperature, solvent, $\mathrm{pH}$, particle size, pressure, agitation speed, and sample-to-solvent ratio) $[6,9,11]$.

Compared to the currently employed conventional extraction (CE) techniques, advanced techniques have advantages of shorter extraction time; lower temperature; reduced energy, cost, and organic solvents consumption [12]. As it was previously summarized [8], microwave-assisted extraction (MAE), ultrasound-assisted extraction (UAE), pressurized liquid extraction (PLE), and enzyme-assisted extraction (EAE) have been successfully used for brown algae PS extraction. Although these extraction techniques have different principles of operation, their common goal is breakdown of brown algae cell walls, where most of the bioactive molecules, including fucoidan, are stored [13].

UAE is recognized as an effective extraction technique based on the application of high-frequency sound waves $(>20 \mathrm{kHz})$, and it has been studied for the extraction of bioactive compounds from various plant and algal matrices [14-17]. The ultrasonication technique applies physical forces in the extraction of molecules generated by acoustic cavitation, such as shear, shockwaves, microjets, and acoustic streaming [18], which results in rapid formation and collapse of cavitation bubbles within irradiated liquid medium, leading to intense stress and irreversible chain splitting [19].

Recently, the potential of cold or non-thermal plasma (NTP) in isolation of bioactive molecules has also been explored. NTP is generated by the application of an electric or electromagnetic field to a gas. This accelerates the free electrons and ionizes the gas atoms and molecules releasing more free electrons, provoking new ionizations and producing molecular dissociations [20]. Therefore, the plasma is constituted of molecules and atoms in an excited state, positive and negative ions, free radicals, electrons, UV radiation, and reactive oxygen and nitrogen species such as ozone, hydroxyl radicals, superoxide, atomic oxygen, singlet oxygen, nitric oxide, or nitrogen dioxide [20]. These reactive species could damage cell structure, rapidly and easily diffuse into the cells, and provoke damage of lipids, proteins, nucleic acids, and carbohydrates [20]. In the food industry, NTP is mostly used for food preservation and maintenance of food safety due to the fact of its effectiveness in microbial inactivation. However, some studies also reported its application in phenolics extraction from tomato pomace [21], essential oil extraction [22-25], lipid extraction from microalgae Nannochloropsis gaditana [26], and as a pre-extraction procedure prior to Soxhlet extraction from coffee grounds [27]. To the best of our knowledge, there are no reported studies on the use of NTP for algal PS extraction.

Since physicochemical properties of algal PS are influenced by various parameters, and the aim of this research was to study the effect of different solvents (i.e., $\mathrm{H}_{2} \mathrm{O}$, $0.1 \mathrm{M} \mathrm{HCl}$, and $0.1 \mathrm{M} \mathrm{H}_{2} \mathrm{SO}_{4}$ ) and extraction techniques (i.e., $\mathrm{CE}, \mathrm{UAE}$, and NTP) for their extraction from brown algae F. virsoides and C. barbata and to compare them in terms of yield, chemical composition, and antioxidant capacity. Furthermore, the research goal was to investigate if application of UAE and NTP as a pre-treatment prior to CE would 
cause more cell wall breakage and, consequently, higher yield as well as how it would affect chemical composition of the extracted PS. Overall, this study aimed to determine if the application of advanced extraction techniques could successfully extract algal PS but with a reduced time and lower temperature, which is economically and ecologically more beneficial.

\section{Materials and Methods}

\subsection{Chemicals and Reagents}

All chemicals and reagents used in this research were of analytical grade. Gelatin, L-cysteine, sodium tetraborate, sulfamic acid, chloroform, potassium hydroxide, 6-hydroxy2,5,7,8-tetramethylchroman-2-carboxylic acid (Trolox), and 1-phenyl-3-methyl-5-pyrazolone (PMP) were purchased from Acros Organics (Geel, Belgium). Fucoidan from Fucus vesiculosus, phenol, m-hydroxydiphenyl, D-(+)-glucose, L-(-)-fucose, D-(+)-mannose, D-(-)fructose, D-galacturonic acid, L-rhamnose, arabinose, trimethylamine, ammonium acetate, and 2,2'-azobis(2-methylpropionamidine) dihydrochloride (AAPH) were purchased from Sigma-Aldrich (St. Louis, MO, USA). Ethanol, acetone, potassium sulfate, and sodium carbonate were obtained from Gram-mol Ltd. (Zagreb, Croatia); Folin-Ciocalteu reagent, acetonitrile, trichloroacetic acid (TCA), and silicone oil from Fisher Scientific (Leicestershire, UK); absolute ethanol, hexane, and ethyl acetate from Carlo Erba Reagents (Cornaredo, Italy). Fluorescein sodium salt was purchased from Honeywell Riedel-de-Haën (Bucharest, Romania); barium chloride from abcr GmbH (Karlsruhe, Germany); sodium hydroxide from Lach-Ner (Zagreb, Croatia); D-(-)-ribose from TCI (Portland, OR, USA); sulfuric acid from Scharlab S.L. (Barcelona, Spain); hydrochloric acid $(\mathrm{HCl})$ from TKI Hrastnik (Hrastnik, Slovenia).

\subsection{Algal Material and Preliminary Treatments}

In February 2020, from the coastal region of Zadar (Croatia), marine biologist Donat Petricioli harvested and identified brown algae Fucus virsoides (44 $12^{\prime} 02^{\prime \prime} \mathrm{N} ; 15^{\circ} 28^{\prime} 51^{\prime \prime} \mathrm{E}$ ) and Cystoseira barbata $\left(44^{\circ} 12^{\prime} 42^{\prime \prime} \mathrm{N} ; 1^{\circ} 09^{\prime} 23^{\prime \prime} \mathrm{E}\right)$ (Figure 1$)$. Freshly harvested algae were washed, frozen at $-60{ }^{\circ} \mathrm{C}$ (ScanCool SCL210P, Labogene ApS, Lillerød, Denmark), and freeze-dried (CoolSafe lyophilizer, 55-9 PRO, Labogene, Lillerød, Denmark) for $24 \mathrm{~h}$. The freeze-dried algae were milled with an electric grinder WSG30E/K (Waring Commercial, Stamford, CT, USA), and the powder was stored at $-4{ }^{\circ} \mathrm{C}$ for one week before the extraction process.

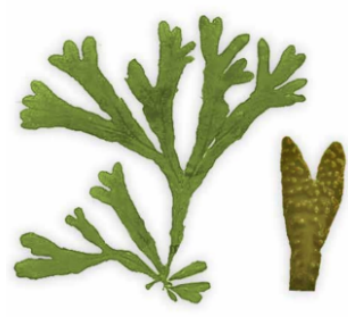

a)

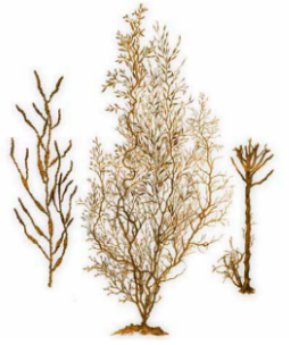

b)

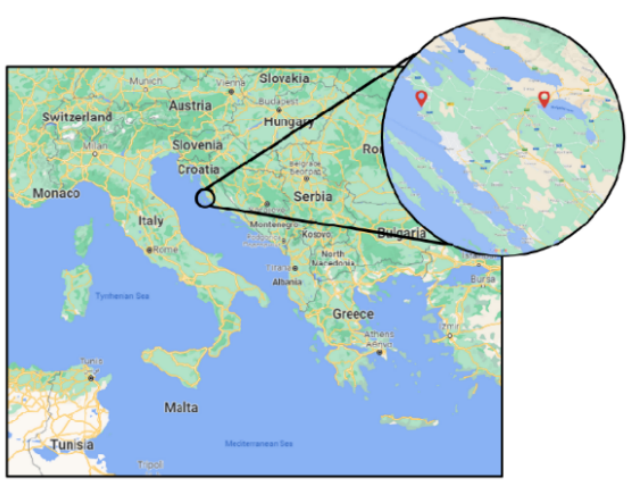

c)

Figure 1. (a) Fucus virsoides; (b) Cystoseira barbata (c); location of seaweed collection.

\subsection{Extraction of PS}

Prior to extraction, a pre-treatment process was performed with continuous stirring in two steps under previously established conditions [28]: $18 \mathrm{~h}$ at room temperature with acetone followed by $4 \mathrm{~h}$ at $70{ }^{\circ} \mathrm{C}$ with $96 \%$ ethanol. After centrifugation, filtration, and 
air-drying, pre-treated dried algae $(1 \mathrm{~g})$ were extracted with $\mathrm{H}_{2} \mathrm{O}, 0.1 \mathrm{M} \mathrm{HCl}$, or $0.1 \mathrm{M}$ $\mathrm{H}_{2} \mathrm{SO}_{4}(30 \mathrm{~mL})$ by the following procedures (Figure 2):

(a) $\mathrm{CE}$ for $3 \mathrm{~h}$ at $80^{\circ} \mathrm{C}$ under constant stirring (400 rpm) [28];

(b) UAE with an ultrasonic homogenizer UP200HT (200 W, $26 \mathrm{kHz}$ ) (Hielscher, Teltow, Germany), titanium sonotrode $\varnothing 14 \mathrm{~mm}\left(154 \mathrm{~mm}^{2}\right)$ for $30 \mathrm{~min}$ at $100 \%$ amplitude, and a cold water bath was used to keep the temperature at approximately $25^{\circ} \mathrm{C}$;

(c) Five minutes of UAE treatment followed by $\mathrm{CE}$ for $3 \mathrm{~h}$ at $80^{\circ} \mathrm{C}$ under constant stirring (400 rpm);

(d) Hybrid NTP with a pulse high-voltage generator HVG60/1 PL (Impel, Croatia) for $30 \mathrm{~min}$; electrical voltage-30 kV; frequency-60 Hz; electric current-10 mA; distance between electrodes- $1 \mathrm{~cm}$; gas-argon at $1 \mathrm{~L} \mathrm{~h}^{-1}$;

(e) Five minutes NTP treatment followed by CE for $3 \mathrm{~h}$ at $80^{\circ} \mathrm{C}$ under constant stirring (400 rpm).

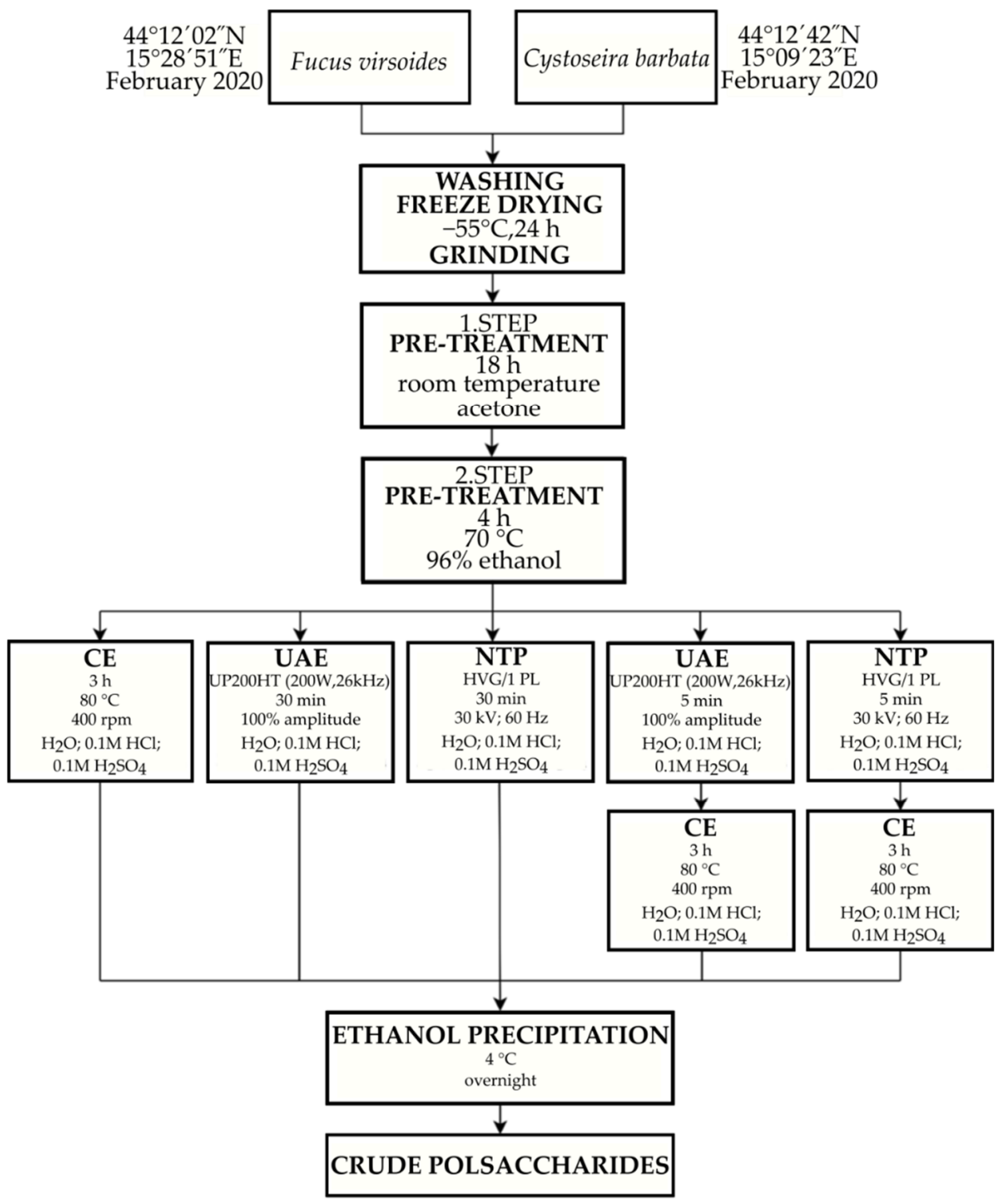

Figure 2. Schematic diagram of the experiment.

Afterwards, a double volume of absolute ethanol $(60 \mathrm{~mL})$ was added to the filtrates in order to precipitate PS. The mixture was kept overnight at $+4{ }^{\circ} \mathrm{C}$ after which it was centrifuged (5500 rpm, $30 \mathrm{~min}$ ), dried for $48 \mathrm{~h}$ at room temperature, and milled in a mortar 
and pestle to a fine powder. Dried samples were stored at $-4{ }^{\circ} \mathrm{C}$. PS extraction yield (\%PS) was calculated according to Equation (1), where WP is the weight obtained after ethanol precipitation, and WA is the algae weight used in each experiment.

$$
\% \mathrm{PS}=\frac{W P}{W A} \times 100
$$

\subsection{Chemical Composition of PS}

The concentration of L-fucose units in algal PS was determined according to the colorimetric assay with L-cysteine, using L-fucose as the standard [29]. Sulfate group content was determined by the turbidimetric barium chloride-gelatin method, with potassium sulfate as the standard, after PS hydrolysis $\left(1 \mathrm{M} \mathrm{HCl}, 105^{\circ} \mathrm{C}, 5 \mathrm{~h}\right)$ [30]. Total sugar content in PS was measured by the colorimetric phenol-sulfuric acid method with glucose as the standard [31]. Uronic acid concentration was determined through modified sulfamate $/ \mathrm{m}$ hydroxydiphenyl colorimetric method with D-galacturonic acid as the standard [32].

\subsection{HPLC Analysis of PS Monosaccharide Composition}

HPLC analysis of PS monosaccharide composition was performed according to the previously described method [33] with some modifications. The PS sample (100.0 mg) was hydrolyzed in $1 \mathrm{M} \mathrm{H}_{2} \mathrm{SO}_{4}(2.0 \mathrm{~mL})$ and incubated in an oil bath at $110{ }^{\circ} \mathrm{C}$ for $4 \mathrm{~h}$. After cooling to a room temperature, $2 \mathrm{M}$ sodium hydroxide was used to neutralize $(\mathrm{pH} 7)$ the reaction mixture. An Internal standard solution $(2 \mathrm{~mL})$ was added, shaken well, diluted to $10 \mathrm{~mL}$, and filtered.

A mixture of filtered hydrolyzed PS solution (or monosaccharide standards) (100 $\mu \mathrm{L})$, 0.5 M methanolic solution of PMP $(100 \mu \mathrm{L})$, and $0.3 \mathrm{M}$ aqueous sodium hydroxide $(100 \mu \mathrm{L})$ was incubated in water bath for $30 \mathrm{~min}$ at $70{ }^{\circ} \mathrm{C}$. Afterwards, the reaction mixture was cooled to a room temperature and neutralized ( $\mathrm{pH} 7$ ) with $0.3 \mathrm{M}$ hydrochloric acid. Chloroform $(1 \mathrm{~mL})$ was added to the solution, shaken well on vortex mixer and centrifuged (5000 rpm, $10 \mathrm{~min}$ ). The chloroform layer was discarded, while the aqueous layer was extracted two more times with chloroform, and the final aqueous layer was analyzed by HPLC.

The internal standard solution was ribose $(\sim 1 \mathrm{mmol})$ (dissolved in water and diluted to $50 \mathrm{~mL}$ ). Five known concentrations of the following monosaccharides standards (mixed with internal standard) were prepared by successive dilutions from stock solutions and injected into the instrument: arabinose $\left(0.25-1.75 \mathrm{mg} \mathrm{mL}^{-1}\right)$, glucose $\left(0.25-2 \mathrm{mg} \mathrm{mL}^{-1}\right)$, fucose $\left(0.1875-1.5 \mathrm{mg} \mathrm{mL}^{-1}\right)$, galacturonic acid $\left(0.25-1.75 \mathrm{mg} \mathrm{mL}^{-1}\right)$, rhamnose $(0.25-1.75$ $\left.\mathrm{mg} \mathrm{mL}^{-1}\right)$, fructose $\left(0.25-1.75 \mathrm{mg} \mathrm{mL}^{-1}\right)$, and mannose $\left(0.25-1.75 \mathrm{mg} \mathrm{mL}^{-1}\right)$. Calibration curves were plotted (Table 1 ) as the ratio of the peak areas of the standard monosaccharide and the internal ribose standard vs. concentration.

Table 1. Calibration curves for PMP sugars.

\begin{tabular}{ccc}
\hline PMP Sugar & Standard Curve & $\boldsymbol{R}^{\mathbf{2}}$ \\
\hline fucose & $\mathrm{y}=0.3549 \mathrm{x}-0.0712$ & 0.9940 \\
glucose & $\mathrm{y}=2.8327 \mathrm{x}-0.6781$ & 0.9925 \\
arabinose & $\mathrm{y}=1.2784 \mathrm{x}-0.2645$ & 0.9948 \\
galacturonic acid & $\mathrm{y}=2.3517 \mathrm{x}-0.6414$ & 0.9951 \\
fructose & $\mathrm{y}=0.1633 \mathrm{x}-0.0453$ & 0.9925 \\
rhamnose & $\mathrm{y}=0.0706 \mathrm{x}+0.0064$ & 0.9961 \\
\hline
\end{tabular}

An HPLC Agilent Infinity 1260 system (Agilent Technologies, Santa Clara, CA, USA) equipped with UV/Vis and DAD, an automatic injector, ChemStation software, and a Zorbax Eclipse XDB-C18 column $(4.5 \times 250$ mm, 5 um) (Agilent Technologies, Santa Clara, CA, USA) were used for monosaccharide analysis. A mixture of $0.4 \%$ trimethylamine in $20 \mathrm{mmol} \mathrm{L}^{-1}$ ammonium acetate buffer solution ( $\mathrm{pH} 6.30$ with acetic acid) and acetonitrile 
(9:1) was used as solvent $\mathrm{A}$, while a mixture of $0.4 \%$ triethylamine in $20 \mathrm{mmol} \mathrm{L}^{-1}$ ammonium acetate buffer solution ( $\mathrm{pH} 6.30$ with acetic acid) and acetonitrile (4:6) was used as solvent $B$. Chromatographic separation was achieved with the following gradient: 0-9 min, $10-14 \% \mathrm{~B}$; $9-30 \mathrm{~min}, 64 \% \mathrm{~B} ; 30-35 \mathrm{~min}, 64 \% \mathrm{~B}$; and $35-37 \mathrm{~min}, 10 \% \mathrm{~B}$. The mobile phase flow rate was set at $1 \mathrm{~mL} \mathrm{~min}{ }^{-1}$, column temperature at $25^{\circ} \mathrm{C}$, injection volume at $10 \mu \mathrm{L}$, and the chromatograms were monitored at $245 \mathrm{~nm}$. All experiments were carried out in duplicate.

\subsection{Determination of Molecular Properties}

High-performance size exclusion chromatography with refraction index detector (HPSEC-RID) was used to assess molecular properties (average molecular weight $\left(\mathrm{M}_{\mathrm{w}}\right)$, the number average molecular weight $\left(\mathrm{M}_{\mathrm{n}}\right)$, and the polydispersity index (PDI)) of F. virsoides and C. barbata PS extracted with CE, UAE, and NTP with $\mathrm{H}_{2} \mathrm{SO}_{4}$. The 1260 Infinity II LC system (Agilent Technologies) consisted of a quaternary gradient pump G7111B, an autosampler G4767A, a multicolumn thermostat G7116A, and a refraction index detector G7162A. HPSEC analysis was performed using PL aqua gel-OH guard column $(8 \mu \mathrm{m}$, $50 \times 7.5 \mathrm{~mm}$; Agilent Technologies) and PL aqua gel-OH MIXED-M column $(8 \mu \mathrm{m}$, $300 \times 7.5 \mathrm{~mm}$; Agilent Technologies). Column temperature was $30^{\circ} \mathrm{C}$, RID temperature was $40^{\circ} \mathrm{C}$, mobile phase was $\mathrm{H}_{2} \mathrm{O}$, flow rate was $0.5 \mathrm{~mL} \mathrm{~min}^{-1}$, and injection volume was $50 \mu \mathrm{L}$. Pullulan standards (Agilent Technologies), with $\mathrm{M}_{\mathrm{w}}$ in a range from 180 to $700 \mathrm{kDa}$, were used to construct a molecular weight calibration curve and OpenLAB CDS ChemStation Edition (Agilent Technologies) was used for data collection and processing.

\subsection{Oxygen Radical Absorbance Capacity (ORAC) Assay}

The ORAC assay was used to measure the antioxidant capacity in F. virsoides and C. barbata PS extracts obtained with $\mathrm{CE}, \mathrm{UAE}$, and NTP with $\mathrm{H}_{2} \mathrm{SO}_{4}$ [34]. An automated plate reader (BMG LABTECH, Offenburg, Germany) with 96-well plates was used, and data were analyzed by MARS 2.0 software. Fluorescein solution, AAPH, and different Trolox dilutions were prepared in $75 \mu \mathrm{M}$ phosphate buffer ( $\mathrm{pH}$ 7.4). After dissolving dry PS in $\mathrm{ddH}_{2} \mathrm{O}\left(4 \mathrm{mg} \mathrm{mL}^{-1}\right)$ and filtration, samples were added in a 96-well black plate containing a fluorescein solution $(70.3 \mathrm{nM})$. The plate was incubated at $37^{\circ} \mathrm{C}$ for $30 \mathrm{~min}$, and after the first three cycles (representing the baseline signal) to initiate the peroxyl radical generation, AAPH $(240 \mathrm{mM})$ was injected into each well. Different Trolox dilutions $(3.12-103.99 \mu \mathrm{M})$ were used as the reference standard. During a total measurement time of $120 \mathrm{~min}$, fluorescence intensity (emission at $528 \mathrm{~nm}$ and excitation at $485 \mathrm{~nm}$ ) was observed every $90 \mathrm{~s}$.

\subsection{DPPH Radical Scavenging Assay}

Spectrophotometric assay was used to measure the ability of the extracts to scavenge DPPH radical. Polysaccharide solution $\left(1 \mathrm{mg} \mathrm{mL}^{-1}\right)(1.5 \mathrm{~mL})$ was mixed with DPPH solution $(0.2 \mathrm{mM}$ in $70 \%$ ethanol) $(1.5 \mathrm{~mL})$, shaken on a vortex mixer, and kept at room temperature, in dark, for $30 \mathrm{~min}$. Absorbance decrease was measured at $517 \mathrm{~nm}$ in duplicate. The free radical scavenging activity was calculated according to Equation (2):

$$
\text { Scavenging effect }(\%)=\frac{\mathrm{A}-\mathrm{C}}{\mathrm{A}} \times 100
$$

where A is the control absorbance (DPPH without sample), and C is the sample absorbance.

\subsection{Statistical Analysis}

All extractions and measurements, apart from molecular properties determination, were performed in duplicate. The results were analyzed for statistical significance at $p \leq 0.05$, using the STATISTICA 8.0 software (StatSoft Inc., Tulsa, OK, USA). Continuous variables were analyzed by multifactor analysis of variance (ANOVA) and marginal means were compared with Tukey's HSD multiple comparison tests. Dependent variables were: 
$\% \mathrm{PS}$, sulfate group content (\%), and fucose content (\%), while independent variables were: (a) seaweed species (C. barbata and F. virsoides), (b) solvent $\left(\mathrm{H}_{2} \mathrm{O}, 0.1 \mathrm{M} \mathrm{HCl}\right.$ and $0.1 \mathrm{M}$ $\mathrm{H}_{2} \mathrm{SO}_{4}$ ), and (c) treatment (CE, 30 min UAE, 5 min UAE + CE, 30 min NTP and 5 min NTP $+\mathrm{CE}$ ). For comparison of different extraction techniques (CE, UAE, and NTP-independent variable) one-way ANOVA with Tukey's HSD multiple comparison tests were used, where the dependent variables were \%PS, total sugar, fucose, sulfate group, uronic acid content, monosaccharide composition, $\mathrm{M}_{\mathrm{w}}, \mathrm{M}_{\mathrm{n}}$, and PDI. The design matrix for the experiment and the regression model for each response were calculated as follows [35]:

$$
Y=\beta_{0}+\sum \beta_{\mathrm{i}} \mathrm{X}_{\mathrm{i}}+\sum \beta_{\mathrm{ii}} \mathrm{X}_{\mathrm{i}}^{2}+\sum \beta_{\mathrm{ij}} \mathrm{X}_{\mathrm{i}} \mathrm{X}_{\mathrm{j}}
$$

where $\mathrm{Y}$ is the predicted response; $\beta_{0}$ is the fixed response; $\beta_{\mathrm{i}}, \beta_{\mathrm{ii}}$, and $\beta_{\mathrm{ij}}$ are the linear, quadratic, and interaction coefficients; $X_{i}$ and $X_{j}$ are independent factors.

\section{Results and Discussion}

\subsection{Influence of Algal Species, Solvent, and Extraction Technique on PS Yield}

PS from F. virsoides and C. barbata were extracted using CE as well as advanced techniques: UAE and NTP. Furthermore, UAE and NTP were also applied as $5 \mathrm{~min}$ pretreatments prior to $\mathrm{CE}$. The use of three different extraction solvents (i.e., $\mathrm{H}_{2} \mathrm{O}, 0.1 \mathrm{M}$ $\mathrm{HCl}$, and $0.1 \mathrm{M} \mathrm{H}_{2} \mathrm{SO}_{4}$ ) was also examined on yield and chemical composition of the extracted PS. It is necessary to emphasize that all extracts analyzed in this study were crude (not purified) extracts; thus, it was more accurate to report them as \%PS rather than fucoidan yield.

Influence of algae species, extraction solvent, and extraction treatment on polysaccharide yield (\%PS), sulfate group, and fucose content of the extracted polysaccharides is shown in Table 2 and regression model equations in Table 3. All studied parameters had a significant $(p \leq 0.05)$ influence on \%PS. Average crude \%PS from F. virsoides was $9.75 \%$ and from C. barbata $8.86 \%$. Although both of these seaweeds are order Fucales, PS\% highly depended on seaweed species, and within the same species it is also influenced by several other factors, such as extraction procedure and solvent, harvest season, and geographic location as well as the maturity of the plant [36,37]. Usov et al. [38] reported that \%PS from 25 different brown seaweed species ranged between $0.4 \%$ and $20.4 \%$, while in the study of Turan et al. [39] they constituted up to 25-30\%. The only commercially available fucoidan is prepared from Fucus vesiculosus [7] which is, along with Fucus evanescens, especially attractive as the PS source due to the fact of their wide growth area, growth in shallow waters, and large amounts of alginic acid, fucoidan, and mannitol [38]. On the other hand, F. virsoides is a species of brown alga endemic to the Adriatic Sea, and it has not been used for PS extraction so far. When comparing the obtained results with the literature [28], PS\% of the Fucus genus seaweed have been reported to be as high as $21.5 \%$ for F. distichus [40] and as low as $1.40 \%$ for $F$. vesiculosus [41]. The \%PS of C. barbata obtained in this research was slightly higher than other similar studies performed on different seaweed from Cystoseira genus, where it ranged from $2.8 \%$ for $C$. crinite [42] to $5.45 \%$ for $C$. barbata [43].

A remarkable significant difference $(p \leq 0.05)$ in \%PS between different solvents was observed. The highest \%PS (15.45\%) obtained with $0.1 \mathrm{M} \mathrm{H}_{2} \mathrm{SO}_{4}$ was more than two-fold higher in comparison with \%PS obtained with $\mathrm{H}_{2} \mathrm{O}(5.67 \%)$ and $0.1 \mathrm{M} \mathrm{HCl}(6.80 \%)$. PS extraction was probably facilitated due to the cell wall hydrolysis, which is caused by acid application [44]. Similarly, use of $\mathrm{H}_{2} \mathrm{O}$ gave more than a two-fold lower \%PS than when $1 \mathrm{M} \mathrm{HCl}$ was used in research of brown seaweed Sargassum fusiforme by Liu et al. [44]. Since \%PS obtained by $0.1 \mathrm{M} \mathrm{H}_{2} \mathrm{SO}_{4}$ with $\mathrm{pH} 0.7$ was much higher than \%PS obtained by $0.1 \mathrm{M}$ $\mathrm{HCl}$ with $\mathrm{pH} 1$, it appeared that lowering the $\mathrm{pH}$ increased the $\mathrm{PS} \%$ [45]. Similar findings were reported by Ptak et al. [45], who achieved marginally better fucoidan and laminarin yield with $100 \mathrm{mM} \mathrm{HCl}\left(\mathrm{pH}\right.$ 2) then with $10 \mathrm{mM} \mathrm{H}_{2} \mathrm{SO}_{4}$ (pH 4) for Fucus seaweed harvested in France. However, they reported opposite observations for the Fucus seaweed harvested 
in Germany. Considering these results, $\mathrm{H}_{2} \mathrm{SO}_{4}$ was chosen as optimal solvent and further used for comparison of the extraction techniques.

Table 2. Influence of the algae species, extraction solvent, and extraction treatment on polysaccharide yield (\%PS), sulfate group, and fucose content of the extracted polysaccharides.

\begin{tabular}{|c|c|c|c|c|}
\hline & $\mathbf{N}$ & $\%$ PS & Sulfate Group (\%) & Fucose (\%) \\
\hline Algae & & $p \leq 0.05^{*}$ & $p \leq 0.05 *$ & $p \leq 0.05 *$ \\
\hline F. virsoides & 30 & $9.75 \pm 0.04^{b}$ & $41.98 \pm 0.38^{a}$ & $31.68 \pm 0.20^{b}$ \\
\hline C. barbata & 30 & $8.86 \pm 0.04^{\mathrm{a}}$ & $53.60 \pm 0.38^{b}$ & $11.19 \pm 0.20^{\mathrm{a}}$ \\
\hline Solvent & & $p \leq 0.05^{*}$ & $p \leq 0.05^{*}$ & $p \leq 0.05^{*}$ \\
\hline $\mathrm{H}_{2} \mathrm{O}$ & 20 & $5.67 \pm 0.05^{\mathrm{a}}$ & $32.50 \pm 0.47^{\mathrm{a}}$ & $21.33 \pm 0.24^{b}$ \\
\hline $0.1 \mathrm{M} \mathrm{HCl}$ & 20 & $6.80 \pm 0.05^{b}$ & $38.02 \pm 0.47^{\mathrm{b}}$ & $25.97 \pm 0.24^{\mathrm{c}}$ \\
\hline $0.1 \mathrm{M} \mathrm{H}_{2} \mathrm{SO}_{4}$ & 20 & $15.45 \pm 0.05^{\mathrm{c}}$ & $72.86 \pm 0.47^{c}$ & $17.00 \pm 0.24^{\mathrm{a}}$ \\
\hline Treatment & & $p \leq 0.05^{*}$ & $p \leq 0.05 *$ & $p \leq 0.05^{*}$ \\
\hline $\mathrm{CE}$ & 12 & $11.7 \overline{4} \pm 0.06^{\mathrm{e}}$ & $42.7 \overline{4} \pm 0.61^{a}$ & $32.41 \pm 0.31^{\mathrm{e}}$ \\
\hline UAE $5 \mathrm{~min}+\mathrm{CE}$ & 12 & $11.41 \pm 0.06^{\mathrm{d}}$ & $47.92 \pm 0.61^{b}$ & $25.73 \pm 0.31^{\mathrm{c}}$ \\
\hline UAE $30 \mathrm{~min}$ & 12 & $6.72 \pm 0.06^{\mathrm{a}}$ & $44.32 \pm 0.61^{a}$ & $27.29 \pm 0.31^{\mathrm{d}}$ \\
\hline NTP 5 min + CE & 12 & $9.39 \pm 0.06^{c}$ & $42.12 \pm 0.61^{a}$ & $11.96 \pm 0.31^{b}$ \\
\hline NTP $30 \mathrm{~min}$ & 12 & $7.29 \pm 0.06^{b}$ & $61.87 \pm 0.61^{c}$ & $9.76 \pm 0.31^{\mathrm{a}}$ \\
\hline Algae; solvent & & $p \leq 0.05 *$ & $p=0.07$ & $p \leq 0.05^{*}$ \\
\hline F. virsoides; $\mathrm{H}_{2} \mathrm{O}$ & 10 & $7.18 \pm 0.06^{c}$ & $27.44 \pm 0.67^{\mathrm{a}}$ & $35.41 \pm 0.34^{\mathrm{d}}$ \\
\hline $\begin{array}{c}\text { F. virsoides; } 0.1 \mathrm{M} \\
\mathrm{HCl}\end{array}$ & 10 & $7.72 \pm 0.06^{d}$ & $32.33 \pm 0.67^{b}$ & $39.34 \pm 0.34^{e}$ \\
\hline $\begin{array}{l}\text { F. virsoides; } 0.1 \mathrm{M} \\
\qquad \mathrm{H}_{2} \mathrm{SO}_{4}\end{array}$ & 10 & $14.35 \pm 0.06^{\mathrm{e}}$ & $66.19 \pm 0.67^{\mathrm{e}}$ & $20.29 \pm 0.34^{c}$ \\
\hline C. barbata; $\mathrm{H}_{2} \mathrm{O}$ & 10 & $4.16 \pm 0.06^{\mathrm{a}}$ & $37.56 \pm 0.67^{c}$ & $7.25 \pm 0.34^{\mathrm{a}}$ \\
\hline $\begin{array}{c}\text { C. barbata; } 0.1 \mathrm{M} \\
\mathrm{HCl}\end{array}$ & 10 & $5.87 \pm 0.06^{b}$ & $43.71 \pm 0.67^{\mathrm{d}}$ & $12.61 \pm 0.34^{b}$ \\
\hline $\begin{array}{c}\text { C. barbata; } 0.1 \mathrm{M} \\
\mathrm{H}_{2} \mathrm{SO}_{4}\end{array}$ & 10 & $16.56 \pm 0.06^{\mathrm{f}}$ & $79.54 \pm 0.67^{\mathrm{f}}$ & $13.71 \pm 0.34^{\mathrm{b}}$ \\
\hline Algae; treatment & & $p \leq 0.05 *$ & $p \leq 0.05 *$ & $p \leq 0.05^{*}$ \\
\hline F. virsoides; CE & 6 & $12.6 \overline{4} \pm 0.08^{h}$ & $28.4 \overline{3} \pm 0.86^{\mathrm{a}}$ & $45.2 \overline{7} \pm 0.44^{\mathrm{f}}$ \\
\hline $\begin{array}{l}\text { F. virsoides; UAE } \\
5 \mathrm{~min}+\mathrm{CE}\end{array}$ & 6 & $13.27 \pm 0.08^{\mathrm{i}}$ & $45.09 \pm 0.86^{\mathrm{c}, \mathrm{d}}$ & $40.30 \pm 0.44^{\mathrm{e}}$ \\
\hline $\begin{array}{l}\text { F. virsoides; UAE } \\
30 \mathrm{~min}\end{array}$ & 6 & $7.57 \pm 0.08^{c}$ & $41.76 \pm 0.86^{c}$ & $38.60 \pm 0.44^{\mathrm{e}}$ \\
\hline $\begin{array}{l}\text { F. virsoides; NTP } \\
5 \mathrm{~min}+\mathrm{CE}\end{array}$ & 6 & $10.17 \pm 0.08^{f}$ & $33.66 \pm 0.86^{b}$ & $19.22 \pm 0.44^{\mathrm{d}}$ \\
\hline $\begin{array}{l}\text { F. virsoides; NTP } \\
30 \mathrm{~min}\end{array}$ & 6 & $5.11 \pm 0.08^{a}$ & $60.98 \pm 0.86^{\mathrm{f}, \mathrm{g}}$ & $14.97 \pm 0.44^{c}$ \\
\hline C. barbata; CE & 6 & $10.85 \pm 0.08^{g}$ & $57.04 \pm 0.86^{\mathrm{f}}$ & $19.54 \pm 0.44^{\mathrm{d}}$ \\
\hline $\begin{array}{c}\text { C. barbata; UAE } 5 \\
\min +\mathrm{CE}\end{array}$ & 6 & $9.54 \pm 0.08^{\mathrm{e}}$ & $50.75 \pm 0.86^{\mathrm{e}}$ & $11.16 \pm 0.44^{b}$ \\
\hline $\begin{array}{c}\text { C. barbata; UAE } \\
30 \mathrm{~min}\end{array}$ & 6 & $5.86 \pm 0.08^{b}$ & $46.88 \pm 0.86^{\mathrm{d}, \mathrm{e}}$ & $15.98 \pm 0.44^{\mathrm{c}}$ \\
\hline $\begin{array}{c}\text { C. barbata; NTP } 5 \\
\text { min }+ \text { CE }\end{array}$ & 6 & $8.60 \pm 0.08^{d}$ & $50.58 \pm 0.86^{\mathrm{e}}$ & $4.71 \pm 0.44^{\mathrm{a}}$ \\
\hline $\begin{array}{c}\text { C. barbata; NTP } \\
30 \mathrm{~min}\end{array}$ & 6 & $9.47 \pm 0.08^{\mathrm{e}}$ & $62.76 \pm 0.86^{g}$ & $4.54 \pm 0.44^{\mathrm{a}}$ \\
\hline
\end{tabular}

$\overline{\mathrm{CE}}=$ conventional extraction, UAE = ultrasound-assisted extraction, and NTP = non-thermal plasma. Results are expressed as the mean \pm SE. * Statistically significant variable at $p \leq 0.05$. Values with different letters within column are statistically different at $p \leq 0.05$.

As it can be seen in Table 2, none of the advanced treatments, alone or in combination with CE, resulted in a yield higher than the one achieved with $3 \mathrm{~h}$ long CE (11.74\%). Application of UAE and NTP for $30 \mathrm{~min}$, without CE, gave significantly lower $(p \leq 0.05) \%$ PS, i.e., $6.72 \%$ and $7.29 \%$, respectively. UAE and NTP as 5 min pre-treatments in combination with 
CE resulted in \%PS of $11.41 \%$ and $9.39 \%$, respectively. These values were higher than those obtained with treatments alone but still lower than the one obtained when using CE. These results indicate that either too short of an extraction time or the lack of higher temperatures could be the reason for lower efficiency of UAE and NTP in PS extraction when compared to CE. This finding is supported by Okolie et al. [13], who obtained Ascophyllum nodosum $\%$ PS of $4.56 \%$ by UAE ( $35 \mathrm{~min}$, amplitude $40 \%$ ) and $11.9 \%$ by CE ( $70{ }^{\circ} \mathrm{C}$ for $3 \times 3 \mathrm{~h}$ ). On the contrary, in research by Hanjabam et al. [46], the UAE method (30 $\mathrm{min}, 50 \%$ amplitude)

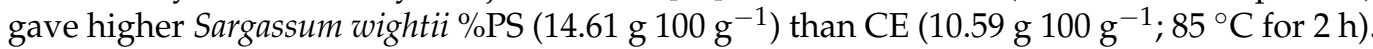
Moreover, in research by Kadam et al. [47], laminarin yield of L. hyperborea and A. nodosum extracted by 15 min UAE treatment was 15.02-91.76\% higher, depending on the solvent.

Table 3. Regression model equations and determination coefficients $\left(R^{2}\right)$ for polysaccharide yield (\%PS), sulfate group, and fucose content.

\begin{tabular}{ccc}
\hline & Regression Model & $R^{2}$ \\
\hline \%PS & $\mathrm{y}=32.81-10.46 \mathrm{X}_{1}-14.02 \mathrm{X}_{2}+$ & \\
& $3.76 \mathrm{X}_{2}{ }^{2}-4.86 \mathrm{X}_{3}+0.27 \mathrm{X}_{3}{ }^{2}+$ & 0.775 \\
& $2.62 \mathrm{X}_{1} \mathrm{X}_{2}+1.45 \mathrm{X}_{1} \mathrm{X}_{3}-0.02 \mathrm{X}_{2} \mathrm{X}_{3}$ & \\
& $\mathrm{y}=51.34+21.11 \mathrm{X}_{1}-51.47 \mathrm{X}_{2}+$ & \\
& $14.66 \mathrm{X}_{2}{ }^{2}-10.55 \mathrm{X}_{3}+2.18 \mathrm{X}_{3}{ }^{2}+$ & \\
Sulfate group (\%) & $1.61 \mathrm{X}_{1} \mathrm{X}_{2}-4.24 \mathrm{X}_{1} \mathrm{X}_{3}+3.53 \mathrm{X}_{2} \mathrm{X}_{3}$ & \\
& $\mathrm{y}=103.44-55.64 \mathrm{X}_{1}+7.30 \mathrm{X}_{2}-$ & \\
Fucose (\%) & $6.81 \mathrm{X}_{2}{ }^{2}-10.34 \mathrm{X}_{3}-0.57 \mathrm{X}_{3}{ }^{2}+$ & \\
& $10.79 \mathrm{X}_{1} \mathrm{X}_{2}+4.52 \mathrm{X}_{1} \mathrm{X}_{3}+0.53 \mathrm{X}_{2} \mathrm{X}_{3}$ & \\
&
\end{tabular}

\subsection{Influence of Algal Species, Solvent, and Extraction Technique on PS Chemical Composition}

As already mentioned, algal PS chemical composition is a key factor in determination of their biological activities; however, it is highly influenced by various parameters. The influence of algal species (F. virsoides, $C$. barbata), solvent $\left(\mathrm{H}_{2} \mathrm{O}, 0.1 \mathrm{M} \mathrm{HCl}, 0.1 \mathrm{M} \mathrm{H}_{2} \mathrm{SO}_{4}\right)$ and extraction method (CE, $30 \mathrm{~min}$ UAE, $30 \mathrm{~min}$ NTP, 5 min UAE + CE, 5 min NTP + CE) on fucose and sulfate group content is shown in Table 1. All studied parameters had a statistically significant $(p<0.05)$ influence on fucose and sulfate group content.

Sulfate group content is particularly important for biological activities, such as antiHIV [48], anticoagulant [49], and antioxidant [50], and on levels below $20 \%$ it leads to a complete loss of antiproliferative and anticoagulant activity [51]. The average sulfate group content of $F$. virsoides obtained in this research was $41.98 \%$, which is slightly above the range (9-40.3\%) reported for the Fucus genus [40,41,51-54]. The average C. barbata sulfate group content obtained in this research was $53.60 \%$, which is higher than the range (14.65-22.3\%) reported for the Cystoseira genus in other studies [43,55-57]. The lower amount of sulfate groups found in F. virsoides when compared to C. barbata indicates the presence of higher amounts of non-sulfated fucose in the linear part of the PS or the lower amount of branching zones that contain sulfated fucose [41]. Acid induces the sulfate ester cleavage so more sulfate groups can be liberated [58,59], which explains the significantly $(p \leq 0.05)$ higher sulfate content that was obtained by acid extractions in comparison to water extraction. However, Liu et al. [44] and Saravana et al. [60] reported opposite results for Sargassum fusiforme and Saccharina japonica, respectively. Average sulfate content obtained by $0.1 \mathrm{M} \mathrm{H}_{2} \mathrm{SO}_{4}$ was almost two-fold higher than the one obtained by $0.1 \mathrm{M} \mathrm{HCl}$. This is in agreement with previous findings that diluted $\mathrm{HCl}$ tends to yield low sulfate fucoidan, while diluted $\mathrm{H}_{2} \mathrm{SO}_{4}$ tends to yield high sulfate fucoidan as it may interfere with sulfate analysis due to the sulfate group in the sulfuric acid [58,59]. Along with seaweed species and harvesting season, extraction technique is one of the most important factors that influences the sulfate group content [46]. For both examined algae, 30 min NTP treatment resulted in significantly $(p \leq 0.05)$ higher sulfate group content. CE gave the lowest sulfate group content in F. virsoides, while in C. barbata the sulfate group content obtained by CE 
was lower than 30 min NPT but higher than any other studied treatment. Okolie et al. [13] reported lower sulfate content in UAE extraction in comparison with CE, while Hanjabam et al. [46] found similar sulfate content obtained with UAE and CE.

Studies have reported that fucose content varies among seaweeds species, extraction techniques [37], extraction conditions [46], harvest time [51,61], plant part [38], and maturity of the seaweed [37], and it was suggested that the higher amount of fucose may contribute to the higher cytotoxic activity of algal PS [62]. The average fucose content obtained in this research was $31.68 \%$ and $11.19 \%$ for F. virsoides and C. barbata, respectively. These values are comparable with values reported by other authors [28]. Contrary to the sulfate group content, $C$. barbata fucose content was significantly lower than in F. virsoides, which indicates higher degree of sulphation for each fucose in C. barbata. The highest fucose content was obtained when using $0.1 \mathrm{M} \mathrm{HCl}$ followed by $\mathrm{H}_{2} \mathrm{O}$ and $0.1 \mathrm{M} \mathrm{H}_{2} \mathrm{SO}_{4}$. Higher fucose content, in fucoidan from sporophytes of Splachnidium rugosum, was also achieved by $0.2 \mathrm{M} \mathrm{HCl}$ than $1 \% \mathrm{H}_{2} \mathrm{SO}_{4}$ [63], and the use of acid $(0.03 \mathrm{M} \mathrm{HCl})$ instead of water resulted in a $6 \%$ increase in the amount of fucose [64]. However, acid might cause unwanted degradation of functional groups attached to the fucoidan backbone which can result in the failure of fucose detection [58]. In present study, fucose content was significantly $(p \leq 0.05)$ higher in extracts obtained by CE than any of the UAE and NTP treatments due to the destructive effect of ultrasound on the structure of fucose [46]. A similar trend of higher fucose content obtained by CE than UAE was previously reported [46], as well as similar fucose content obtained with UAE and conventional hot water extraction $[13,65]$. Both of the NTP treatments lead to lower fucose content than ones obtained with UAE treatments, suggesting that the effect of OH radicals formed with NTP on glycosidic bonds [66] is inferior in comparison with cavitation effect of ultrasound.

Fucoidan antioxidant and anticoagulant bioactivity [67-69] has been positively correlated with sulfate:fucose (or total sugar) ratio, and it was noted that anticoagulant activity remarkably decreased when the ratio was below 1 [69], while fucoidan with ratio below 0.3 had no anticoagulant activity [68]. The average sulfate:fucose ratio obtained in this research was 1.33 (F. virsoides) and 4.79 (C. barbata). Previous studies reported that for F. serratus, the sulfate:fucose ratio ranged between 0.73 and 1.5 [51,70,71], for F. vesiculosus between 1.1 and 2.5 [51,70,72], for $A$. nodosum between 1.1 and 2.7 [51,72,73], for $C$. sedoides between 0.3 and 0.9 [42,58], for C. compressa it was 0.27 [42], and for C. crinite 0.36 [42]. The highest reported sulfate:fucose ratio was 5.2 for Ecklonia maxima [58] fucoidan extracted with $0.15 \mathrm{M} \mathrm{HCl}$. The same E. maxima fucoidan but extracted with water had sulfate:fucose ratio of 0.7. Similar to the results of this research, where extracts obtained with $0.1 \mathrm{M} \mathrm{H}_{2} \mathrm{SO}_{4}$ had a much higher sulfate:fucose ratio than water extracts, Laminaria pallida and Splachnidium rugosum fucoidan extracted with acid had a significantly higher sulfate:fucose ratio [60]. PS obtained with CE had the lowest sulfate:fucose ratio, followed by UAE treatments, while in NTP treatments this ratio was much higher. As it was previously discussed, this higher ratio was the result of higher sulfate group and lower fucose content obtained by NTP treatments. Hanjabam et al. [46] reported that Sargassum witghtii fucoidan had average sulfate:fucose ratio of 0.67 with hot water extraction and 0.72 with UAE.

\subsection{Comparison of $C E, U A E$, and NTP Treatment}

As it was mentioned earlier, $\mathrm{H}_{2} \mathrm{SO}_{4}$ was chosen as the optimal solvent and used for further comparison of $3 \mathrm{~h}$ long CE with 30 min UAE and NTP treatments, in terms of yield, chemical composition, molecular properties, and antioxidative capacity. The results are shown in Tables 3 and 4 and Figure 2. CE was considerably longer and performed on higher temperatures than UAE and NTP, which could explain the higher \%PS, lower amount of sulfate groups, and higher proportion of uronic acids (Table 4) as described by several studies [74-76]. For F. virsoides, \%PS obtained by UAE and NTP was respectively two- and three-fold lower than in CE. It seems as if the UAE and NTP treatments were too short or the temperature was too low for higher PS extraction, since PS extraction was generally a lengthy process. F. virsoides and C. barbata \%PS obtained with CE were $18.53 \%$ and $16.47 \%$, 
while their respective predicted values (from regression model equations) were $18.82 \%$ and $17.65 \%$.

Table 4. Polysaccharide yield (\%PS) and chemical composition of Fucus virsoides and Cystoseira barbata polysaccharides obtained with CE, UAE and NTP.

\begin{tabular}{ccccccc}
\hline & & \% PS & $\begin{array}{c}\text { Total Sugars } \\
\left(\mathbf{m g ~ g}^{-1}\right)\end{array}$ & Fucose (\%) & Sulfate Group (\%) & Uronic Acid (\%) \\
\hline & & $p \leq 0.05^{*}$ & $p \leq 0.05^{*}$ & $p \leq 0.05^{*}$ & $p \leq 0.05^{*}$ & $p \leq 0.05^{*}$ \\
F. virsoides & CE & $18.53 \pm 0.00^{\mathrm{e}}$ & $20.17 \pm 0.00^{\mathrm{e}}$ & $41.54 \pm 0.01^{\mathrm{f}}$ & $28.46 \pm 0.01^{\mathrm{a}}$ & $20.06 \pm 0.00^{\mathrm{e}}$ \\
& $\mathrm{UAE}$ & $12.14 \pm 0.28^{\mathrm{c}}$ & $11.58 \pm 0.58^{\mathrm{d}}$ & $14.75 \pm 0.12^{\mathrm{c}}$ & $83.37 \pm 0.20^{\mathrm{b}}$ & $1.77 \pm 0.35^{\mathrm{b}}$ \\
& NTP & $6.10 \pm 0.20^{\mathrm{a}}$ & $22.95 \pm 0.24^{\mathrm{f}}$ & $9.49 \pm 0.16^{\mathrm{b}}$ & $88.31 \pm 5.56^{\mathrm{b}}$ & $3.68 \pm 0.25^{\mathrm{c}}$ \\
& CE & $16.47 \pm 0.18^{\mathrm{d}}$ & $6.34 \pm 0.18^{\mathrm{b}}$ & $22.53 \pm 0.14^{\mathrm{d}}$ & $35.53 \pm 0.80^{\mathrm{a}}$ & $15.72 \pm 0.34^{\mathrm{d}}$ \\
& $\mathrm{UAE}$ & $11.80 \pm 0.07^{\mathrm{c}}$ & $1.19 \pm 0.12^{\mathrm{a}}$ & $31.70 \pm 0.12^{\mathrm{e}}$ & $90.44 \pm 1.40^{\mathrm{b}}$ & $1.16 \pm 0.02^{\mathrm{a}, \mathrm{b}}$ \\
& NTP & $9.64 \pm 0.15^{\mathrm{b}}$ & $10.120 .28^{\mathrm{c}}$ & $2.83 \pm 0.08^{\mathrm{a}}$ & $88.86 \pm 1,73^{\mathrm{b}}$ & $0.46 \pm 0.04^{\mathrm{a}}$ \\
\hline
\end{tabular}

$\mathrm{CE}=$ conventional extraction, $\mathrm{UAE}=$ ultrasound-assisted extraction , and NTP $=$ non-thermal plasma. Results are expressed as the mean $\pm \mathrm{SD}$. ${ }^{*}$ Statistically significant variable at $p \leq 0.05$. Values with different letters within a column are statistically different at $p \leq 0.05$.

Even though longer extraction time and higher temperatures can lead to fucose chain degradation [37] and consequently lower fucose content [75,77], CE which is considerably longer and performed at higher temperature than UAE and NTP resulted with higher fucose content. Possible explanation could be that the bond between fucoses was disrupted due to the intensive treatment of these advanced techniques. On the contrary, sulfate group content was the lowest in extracts obtained by CE indicating that their bonds were disrupted by long extraction at high temperature rather than cavitation or partially ionized gas. Some research showed that lower uronic acids content is more desirable property of algal PSs since higher uronic acids content shows lower anticoagulant [78] and anticomplement activity [79]. Therefore, UAE and NTP showed an advantage in comparison with CE since significant reduction of uronic acids can be observed in those extracts.

The monosaccharide compositions of CE, UAE, and NTP extracted PSs from F. virsoides and C. barbata are given in Table 4. Generally, in all extracted PSs, L-fucose was the predominant monosaccharide, which was expected and in accordance with most of the previously published studies $[65,67,73,80,81]$. Other detected monosaccharides were glucose, galacturonic acid (oxidized form of D-galactose), and arabinose, while mannose, rhamnose, and fructose were not detected. Our results showed that the monosaccharides ratio varied according to the algal species and extraction method used, which is in accordance with literature data [81]. For both algae, it can be observed that PS extracted with CE had higher fucose and lower glucose content than PS extracted with UAE and NTP. In both algae, PS extracted with UAE had similar concentration of fucose, glucose and galacturonic acid.

HPSEC was used to analyze molecular properties of the PS extracts, and the results of the weight average molecular weight $\left(M_{w}\right)$, the number average molecular weight $\left(M_{n}\right)$, and the polydispersity index (PDI) are presented in Table $5 . \mathrm{M}_{\mathrm{w}}$ is the molecular size of the sample, while $M_{n}$ represents an average molecular weight of all polymer chains within a sample [82]. $M_{w}$ is more influenced by high molecular weight chains, whereas $M_{n}$ is more influenced by the lower molecular weight chains [82]. PDI is the ratio between $M_{w}$ and $\mathrm{M}_{\mathrm{n}}$, and it measures the heterogeneity of molecular weight distributions of polymers, where larger differences between $\mathrm{M}_{\mathrm{w}}$ and $\mathrm{M}_{\mathrm{n}}$ (larger PDI) indicate a more heterogeneous molecular weight distribution [82]. 
Table 5. Monosaccharide composition and molecular properties of Fucus virsoides and Cystoseira barbata polysaccharides obtained with CE, UAE and NTP.

\begin{tabular}{|c|c|c|c|c|c|c|c|c|}
\hline & & \multicolumn{4}{|c|}{ Monosaccharide Composition (\%) } & \multicolumn{3}{|c|}{ Molecular Properties } \\
\hline & & Glucose & Fucose & Galacturonic Acid & Arabinose & $\mathrm{M}_{\mathrm{w}}(\mathrm{kDa})$ & $\mathbf{M}_{\mathbf{n}}$ (kDa) & PDI $\left(M_{w} / M_{n}\right)$ \\
\hline \multirow{4}{*}{ F. virsoides } & & $p \leq 0.05^{*}$ & $p \leq 0.05^{*}$ & $p \leq 0.05^{*}$ & $p \leq 0.05^{*}$ & $p \leq 0.05 *$ & $p \leq 0.05^{*}$ & $p \leq 0.05^{*}$ \\
\hline & $\mathrm{CE}$ & $18.65 \pm 0.24^{a}$ & $44.83 \pm 0.45^{\mathrm{c}}$ & $19.48 \pm 0.26^{b}$ & $17.04 \pm 0.25^{\mathrm{a}}$ & $693.43^{b}$ & $264.42^{b}$ & $2.62^{a, b}$ \\
\hline & UAE & $31.47 \pm 0.32^{b}$ & $36.30 \pm 0.34^{\mathrm{a}}$ & $32.23 \pm 0.31^{\mathrm{d}}$ & n.d. & $1133.78^{\mathrm{e}}$ & $500.16^{\mathrm{e}}$ & $2.27^{a, b}$ \\
\hline & NTP & $46.20 \pm 0.27^{c}$ & $39.83 \pm 0.41^{b}$ & $13.97 \pm 0.14^{\mathrm{a}}$ & n.d. & $16.38^{\mathrm{a}}$ & $16.38^{\mathrm{a}}$ & $1.00^{\mathrm{a}}$ \\
\hline \multirow{3}{*}{ C. barbata } & $\mathrm{CE}$ & n.d. & $100^{\mathrm{e}}$ & n.d. & n.d. & $766.00^{c}$ & $322.87^{c}$ & $2.37^{a, b}$ \\
\hline & UAE & $31.04 \pm 0.29^{b}$ & $35.96 \pm 0.33^{a}$ & $33.00 \pm 0.22^{\mathrm{d}}$ & n.d. & $1651.22^{\mathrm{f}}$ & $616.65^{\mathrm{f}}$ & $2.68^{\mathrm{b}}$ \\
\hline & NTP & $19.15 \pm 0.18^{a}$ & $51.08 \pm 0.23^{d}$ & $29.76 \pm 0.25^{c}$ & n.d. & $930.83^{d}$ & $492.50^{\mathrm{d}}$ & $1.89^{\mathrm{a}, \mathrm{b}}$ \\
\hline
\end{tabular}

$\mathrm{M}_{\mathrm{W}}=$ weight average molecular weight, $\mathrm{M}_{\mathrm{n}}=$ number average molecular weight, $\mathrm{PDI}=$ polydispersity index $\mathrm{CE}=$ conventional extraction, $\mathrm{UAE}=$ ultrasound-assisted extraction, and NTP $=$ non-thermal plasma. Results are expressed as the mean \pm SD. * Statistically significant variable at $p \leq 0.05$. Values with different letters within column are statistically different at $p \leq 0.05$.

The $\mathrm{M}_{\mathrm{w}}$ of CE, UAE, and NTP extracted PSs ranged from 16.38 to $1133.78 \mathrm{kDa}$ for F.virsoides and 766 to $1651.22 \mathrm{kDa}$ for C. barbata. Obtained values were within the range of reported fucoidan $\mathrm{M}_{\mathrm{w}}$ values, 1.4-1323 $\mathrm{kDa}[41,83]$. Algal species, growth conditions, and extraction methodology [82] are some of the factors influencing algal PS molecular weight, therefore explaining the slight difference when comparing measured values with literature ones. According to their molecular weight, fucoidans can be classified as low-molecularweight fucoidans $(<10 \mathrm{kDa})$, medium-molecular-weight fucoidans $(10-10,000 \mathrm{kDa})$, and high-molecular-weight fucoidans (>10,000 kDa) [84]. For both algae, the highest $\mathrm{M}_{\mathrm{W}}$ was achieved in samples obtained by UAE, while the lowest $\mathrm{M}_{\mathrm{W}}$ in $C$. barbata was achieved in samples obtained by $C E$ and F. virsoides by NTP. Likewise, N. zanardinii $\mathrm{M}_{\mathrm{W}}$ obtained by UAE was higher (1021 kDa) than one obtained with CE (823 kDa) [81], while $\mathrm{M}_{\mathrm{w}}$ of $A$. nodosum fucoidan extracted by $\mathrm{CE}(40.2 \mathrm{kDa})$ was significantly lower when compared to samples obtained by UAE (121.1 kDa) [13]. PS was polydispersed with PDIs higher than one unlike natural polymers, such as proteins, which are usually monodispersed with a PDI of approximately one. The PDI of PS extracted in this study ranged from 1 to 2.68 , and it was within the 1-6.2 range of reported fucoidan PDI values [56,81]. For C. barbata, PDI was higher in the samples obtained by UAE, indicating larger degradation during the extraction process, while for F. virsoides, the results were the opposite. Likewise, PDI was lower in N. zanardinii fucoidan extracted with UAE (1.27) in comparison with CE (1.56) [81].

\subsection{Antioxidant Capacity}

The antioxidant capacity of $F$. virsoides and $C$. barbata PS extracts obtained with CE, UAE and NTP, with $\mathrm{H}_{2} \mathrm{SO}_{4}$ as a solvent was assessed with ORAC and DPPH assays. Obtained results are presented in Figure 3. PS from F. virsoides obtained by CE had the highest ORAC value of $37.14 \mu \mathrm{mol} \mathrm{TE}^{-1}$, while UAE and NTP extracts had ORAC values of 19.97 and $20.21 \mu \mathrm{mol} \mathrm{TE} \mathrm{g}^{-1}$, respectively. However, the ORAC value was not significantly different among extraction techniques for C. barbata. For both algae, the highest DPPH value was determined in CE compared to both of the advanced techniques. Despite the fact that antioxidant capacity of fucoidan has been previously proved, the relationship between antioxidant capacity and chemical structure remained unknown. It is recognized that antioxidant capacity is not influenced only by one factor, but rather a combination of few physicochemical characteristics such as sulfate group content, uronic acid content, protein content, and molecular weight [44]. For this reason, correlation between physicochemical characteristics (i.e., sulfate group, uronic acid, $\mathrm{M}_{\mathrm{W}}$, and PDI) and antioxidant measurements (i.e., ORAC and DPPH) were evaluated. For F. virsoides only uronic acid content had strong positive correlation $(r>0.8)$ with ORAC and DPPH values. For $C$. barbata, uronic acid content showed strong positive $(r>0.8)$ and $\mathrm{M}_{\mathrm{W}}$ strong negative $(\mathrm{r}<-0.8)$ correlation with DPPH values. Literature data showed that there was no correlation of ORAC values with the total sulfate content and $\mathrm{M}_{\mathrm{W}}$ of brown algae Lessonia vadosa and red algae Gigartina skottsbergii and Schizymenia binderi [85]. 


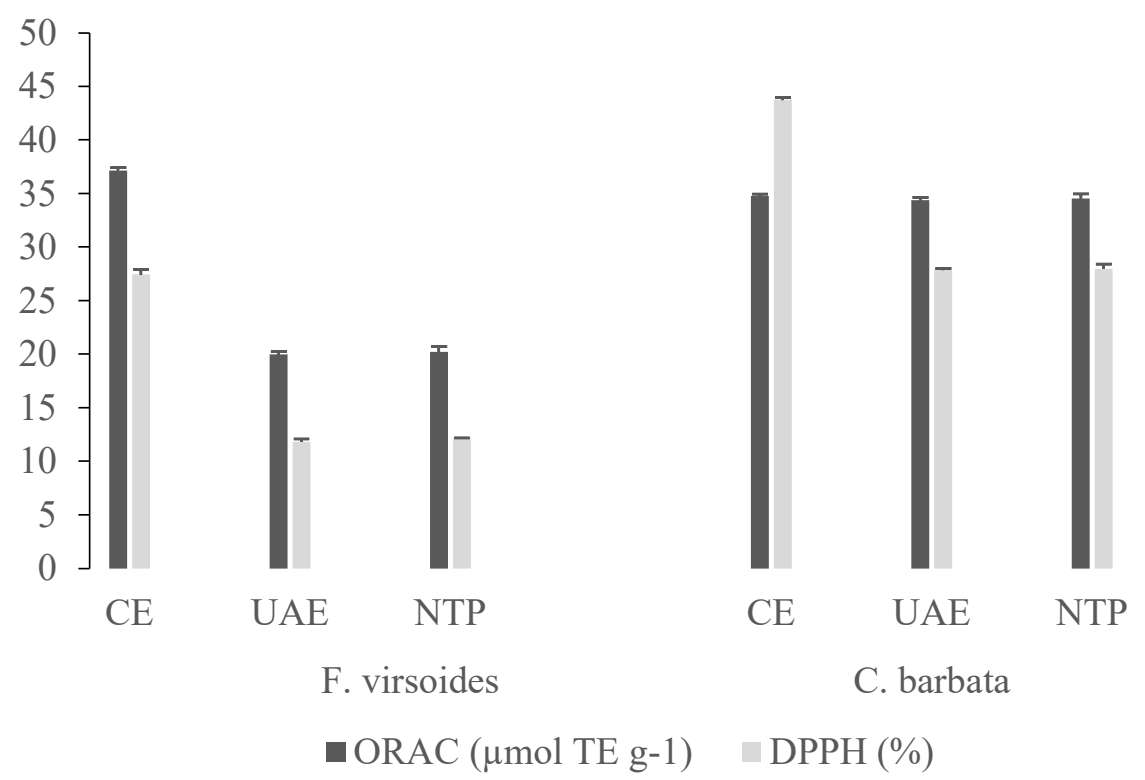

Figure 3. Antioxidant capacity of $F$. virsoides and $C$. barbata polysaccharides obtained by CE, UAE, and NTP as determined by ORAC and DPPH assays.

\section{Conclusions}

The results of present study showed that the advanced extraction techniques, UAE and NTP, have a great potential for F. virsoides and C. barbata PS extraction, even though higher \%PS was achieved with $\mathrm{CE}$, most likely due to the longer extraction time and higher temperatures. However, a significant time reduction, from $3 \mathrm{~h}$ to $30 \mathrm{~min}$, and application of lower temperatures, are beneficial from ecological and economic points of view. Furthermore, both of these advanced techniques resulted in higher amounts of sulfate groups, lower proportions of uronic acids, and higher $\mathrm{M}_{\mathrm{w}}$, which are more desirable properties in terms of PS biological activity. UAE and NTP as 5 min pre-treatments followed by $\mathrm{CE}$ did not cause more cell wall breakage, as they gave more or less comparable \%PS to that of $\mathrm{CE}$ alone.

Diverse biological activities previously attributed to brown algae fucoidan makes them interesting for use in processed and functional food, pharmaceutical, and chemical industries; thus, all these additional improvements in their extraction method could be extremely beneficial from an industrial point of view.

Author Contributions: Conceptualization, methodology, investigation, data curation, writingoriginal draft preparation, A.D.; investigation, M.R. (Marin Roje), S.P., and Z.Z.; writing-review and editing, M.R. (Maja Repajić) and V.D.-U.; supervision, V.D.-U.; funding acquisition, Z.H. and R.Č.-R. All authors have read and agreed to the published version of the manuscript.

Funding: Supported by the BioProCro-Center of Excellence for Marine Bioprospecting and project BioProspecting of the Adriatic Sea co-financed by the Croatian Government and the European Union through the European Regional Development Fund - the Competitiveness and Cohesion Operational Programme (KK.01.1.1.01). This study was funded by the Republic of Croatia Ministry of Science and Education through the European Regional Development Fund through the project (KK.01.1.1.02.0001): "Equipping the Semi-Industrial Practice for the Development of New Food Technologies".

Institutional Review Board Statement: Not applicable.

Informed Consent Statement: Not applicable.

Conflicts of Interest: The authors declare no conflict of interest. 


\section{References}

1. FAO. The State of World Fisheries and Aquaculture 2020. Sustainability in Action; FAO: Rome, Italy, $2020 ;$ ISBN 9789251326923.

2. Guiry, M.D. AlgaeBase. Available online: http://www.algaebase.org/search/genus/detail/?genus_id=71 (accessed on 9 September 2021).

3. Linardić, J. Studije o Jadranskom Fukusu. Acta Bot. Croat. 1949, 12-13, 7-131.

4. Nita, V.; Micu, D.; Nenciu, M. First Attempt of Transplanting the Key-Species Cystoseira Barbata and Zostera Noltei at the Romanian Black Sea Coast. Cercet. Mar. 2014, 44, 147-163.

5. Lim, S.J.; Wan Aida, W.M. Extraction of Sulfated Polysaccharides (Fucoidan) from Brown Seaweed. In Seaweed Polysaccharides: Isolation, Biological and Biomedical Applications; Elsevier: Amsterdam, The Netherlands, 2017; pp. 27-46. ISBN 9780128098172.

6. Ale, M.T.; Mikkelsen, J.D.; Meyer, A.S. Important Determinants for Fucoidan Bioactivity: A Critical Review of Structure-Function Relations and Extraction Methods for Fucose-Containing Sulfated Polysaccharides from Brown Seaweeds. Mar. Drugs 2011, 9 , 2106-2130. [CrossRef] [PubMed]

7. Li, B.; Lu, F.; Wei, X.; Zhao, R. Fucoidan: Structure and Bioactivity. Molecules 2008, 13, 1671-1695. [CrossRef] [PubMed]

8. Dobrinčić, A.; Balbino, S.; Zorić, Z.; Pedisić, S.; Kovačević, D.B.; Garofulić, I.E.; Dragović-Uzelac, V. Advanced Technologies for the Extraction of Marine Brown Algal Polysaccharides. Mar. Drugs 2020, 18, 168. [CrossRef]

9. Garcia-Vaquero, M.; Rajauria, G.; O’Doherty, J.V.; Sweeney, T. Polysaccharides from Macroalgae: Recent Advances, Innovative Technologies and Challenges in Extraction and Purification. Food Res. Int. 2017, 99, 1011-1020. [CrossRef] [PubMed]

10. Jiao, G.; Yu, G.; Zhang, J.; Ewart, H.S. Chemical Structures and Bioactivities of Sulfated Polysaccharides from Marine Algae. Mar. Drugs 2011, 9, 196-233. [CrossRef]

11. Praveen, M.A.; Parvathy, K.R.K.; Balasubramanian, P.; Jayabalan, R. An Overview of Extraction and Purification Techniques of Seaweed Dietary Fibers for Immunomodulation on Gut Microbiota. Trends Food Sci. Technol. 2019, 92, 46-64. [CrossRef]

12. Zia, S.; Khan, M.R.; Shabbir, M.A.; Aslam Maan, A.; Khan, M.K.I.; Nadeem, M.; Khalil, A.A.; Din, A.; Aadil, R.M. An Inclusive Overview of Advanced Thermal and Nonthermal Extraction Techniques for Bioactive Compounds in Food and Food-Related Matrices. Food Rev. Int. 2020. [CrossRef]

13. Okolie, C.L.; Mason, B.; Mohan, A.; Pitts, N.; Udenigwe, C.C. The Comparative Influence of Novel Extraction Technologies on In Vitro Prebiotic-Inducing Chemical Properties of Fucoidan Extracts from Ascophyllum nodosum. Food Hydrocoll. 2019, 90, 462-471. [CrossRef]

14. Dobrinčić, A.; Repajic, M.; Elez Garofulić, I.; Tuđen, L.; Dragović-Uzelac, V.; Levaj, B. Comparison of Different Extraction Methods for the Recovery of Olive Leaves Polyphenols. Processes 2020, 8, 1008. [CrossRef]

15. Okolie, C.L.; Mason, B.; Mohan, A.; Pitts, N.; Udenigwe, C.C. Extraction Technology Impacts on the Structure-Function Relationship between Sodium Alginate Extracts and Their In Vitro Prebiotic Activity. Food Biosci. 2020, 37, 100672. [CrossRef]

16. Rodrigues, S.; Pinto, G.A.S. Ultrasound Extraction of Phenolic Compounds from Coconut (Cocos nucifera) Shell Powder. J. Food Eng. 2007, 80, 869-872. [CrossRef]

17. Muñiz-Márquez, D.B.; Martínez-Ávila, G.C.; Wong-Paz, J.E.; Belmares-Cerda, R.; Rodríguez-Herrera, R.; Aguilar, C.N. UltrasoundAssisted Extraction of Phenolic Compounds from Laurus nobilis L. and Their Antioxidant Activity. Ultrason. Sonochem. 2013, 20, 1149-1154. [CrossRef] [PubMed]

18. Feng, L.; Cao, Y.; Xu, D.; Wang, S.; Zhang, J. Molecular Weight Distribution, Rheological Property and Structural Changes of Sodium Alginate Induced by Ultrasound. Ultrason. Sonochem. 2017, 34, 609-615. [CrossRef] [PubMed]

19. Yan, J.K.; Wang, Y.Y.; Ma, H.L.; Wang, Z. Bin Ultrasonic Effects on the Degradation Kinetics, Preliminary Characterization and Antioxidant Activities of Polysaccharides from Phellinus linteus Mycelia. Ultrason. Sonochem. 2016, 29, 251-257. [CrossRef]

20. López, M.; Calvo, T.; Prieto, M.; Múgica-Vidal, R.; Muro-Fraguas, I.; Alba-Elías, F.; Alvarez-Ordóñez, A. A Review on NonThermal Atmospheric Plasma for Food Preservation: Mode of Action, Determinants of Effectiveness, and Applications. Front. Microbiol. 2019, 10, 622. [CrossRef]

21. Bao, Y.; Reddivari, L.; Huang, J.Y. Development of Cold Plasma Pretreatment for Improving Phenolics Extractability from Tomato Pomace. Innov. Food Sci. Emerg. Technol. 2020, 65, 102445. [CrossRef]

22. Sharanyakanth, P.S.; Lokeswari, R.; Mahendran, R. Plasma Bubbling Effect on Essential Oil Yield, Extraction Efficiency, and Flavor Compound of Cuminum cyminum L. Seeds. J. Food Process. Eng. 2021, 44, e13730. [CrossRef]

23. Ebadi, M.T.; Abbasi, S.; Harouni, A.; Sefidkon, F. Effect of Cold Plasma on Essential Oil Content and Composition of Lemon Verbena. Food Sci. Nutr. 2019, 7, 1166-1171. [CrossRef]

24. Kodama, S.; Thawatchaipracha, B.; Sekiguchi, H. Enhancement of Essential Oil Extraction for Steam Distillation by DBD Surface Treatment. Plasma Process. Polym. 2014, 11, 126-132. [CrossRef]

25. Pragna, C.H.; Ranjitha Gracy, T.K.; Mahendran, R.; Anandharamakrishnan, C. Effects of Microwave and Cold Plasma Assisted Hydrodistillation on Lemon Peel Oil Extraction. Int. J. Food Eng. 2019, 15, 20190093. [CrossRef]

26. Matos, Â.P.; Teixeira, M.S.; Corrêa, F.M.P.S.; Machado, M.M.; Werner, R.I.S.; Aguiar, A.C.; Cubas, A.L.V.; Sant'Anna, E.S.; Moecke, E.H.S. Disruption of Nannochloropsis Gaditana (Eustigmatophyceae) Rigid Cell Wall by Non-Thermal Plasma Prior to Lipid Extraction and Its Effect on Fatty Acid Composition. Braz. J. Chem. Eng. 2019, 36, 1419-1428. [CrossRef]

27. Leal Vieira Cubas, A.; Medeiros Machado, M.; Tayane Bianchet, R.; Alexandra da Costa Hermann, K.; Alexsander Bork, J.; Angelo Debacher, N.; Flores Lins, E.; Maraschin, M.; Sousa Coelho, D.; Helena Siegel Moecke, E. Oil Extraction from Spent Coffee Grounds Assisted by Non-Thermal Plasma. Sep. Purif. Technol. 2020, 250, 117171. [CrossRef] 
28. Dobrinčić, A.; Dobroslavić, E.; Pedisić, S.; Balbino, S.; Elez Garofulić, I.; Čož-Rakovac, R.; Dragović-Uzelac, V. The Effectiveness of the Fucus Virsoides and Cystoseira Barbata Fucoidan Isolation as a Function of Applied Pre-Treatment and Extraction Conditions. Algal Res. 2021, 56, 102286. [CrossRef]

29. Dische, Z.; Shettles, L.B. A Specific Color Reaction of Methylpentoses and a Spectrophotometric Micromethod for Their Determination. J. Biol. Chem. 1948, 175, 595-603. [CrossRef]

30. Dodgson, K.S.; Price, R.G. A Note on the Determination of the Ester Sulphate Content of Sulphated Polysaccharides. Biochem. J. 1962, 84, 106-110. [CrossRef]

31. Dubois, M.; Gilles, K.; Hamilton, J.; Rebus, P.; Smith, F. Colorimetric Method for the Determination of Sugars and Related Substances. Anal. Chem. 1956, 28, 350-356. [CrossRef]

32. Filisetti-Cozzi, T.M.C.C.; Carpita, N.C. Measurement of Uronic Acids without Interference from Neutral Sugars. Anal. Biochem. 1991, 197, 157-162. [CrossRef]

33. Zhang, J.; Zhang, Q.; Wang, J.; Shi, X.; Zhang, Z. Analysis of the Monosaccharide Composition of Fucoidan by Precolumn Derivation HPLC. Chin. J. Oceanol. Limnol. 2009, 27, 578-582. [CrossRef]

34. Elez Garofulić, I.; Kruk, V.; Martić, A.; Martić, I.; Zorić, Z.; Pedisić, S.; Dragović, S.; Dragović-Uzelac, V. Evaluation of Polyphenolic Profile and Antioxidant Activity of Pistacia lentiscus L. Leaves and Fruit Extract Obtained by Optimized Microwave-assisted Extraction. Foods 2020, 9, 1556. [CrossRef] [PubMed]

35. Khuri, A.I.; Cornell, J.A. Response Surfaces: Designs and Analyses, 2nd ed.; Psychological Reports; CRC Press: Boca Raton, FL, USA, 1996.

36. García-Ríos, V.; Ríos-Leal, E.; Robledo, D.; Freile-Pelegrin, Y. Polysaccharides Composition from Tropical Brown Seaweeds. Phycol. Res. 2012, 60, 305-315. [CrossRef]

37. Baba, B.M.; Mustapha, W.A.W.; Joe, L.S. Effect of Extraction Methods on the Yield, Fucose Content and Purity of Fucoidan from Sargassum sp. Obtained from Pulau Langkawi, Malaysia. Malays. J. Anal. Sci. 2018, 22, 87-94. [CrossRef]

38. Usov, A.I.; Smirnova, G.P.; Klochkova, N.G. Polysaccharides of Algae: 55. Polysaccharide Composition of Several Brown Algae from Kamchatka. Russ. J. Bioorg. Chem. 2001, 27, 395-399. [CrossRef]

39. Turan, G. Determination of the Seasonal Yields of Total Fucose and Fucoidan Yields in Brown Seaweeds (Order Fucales) Distributed along the Coast of Urla (Izmir, Turkey). HSOA J. Aquac. Fish. 2017, 1, 005. [CrossRef]

40. Bilan, M.I.; Grachev, A.A.; Ustuzhanina, N.E.; Shashkov, A.S.; Nifantiev, N.E.; Usov, A.I. A Highly Regular Fraction of a Fucoidan from the Brown Seaweed Fucus distichus L. Carbohydr. Res. 2004, 339, 511-517. [CrossRef]

41. Rioux, L.E.; Turgeon, S.L.; Beaulieu, M. Characterization of Polysaccharides Extracted from Brown Seaweeds. Carbohydr. Polym. 2007, 69, 530-537. [CrossRef]

42. Ammar, H.H.; Lajili, S.; Said, R.B.; Le Cerf, D.; Bouraoui, A.; Majdoub, H. Physico-Chemical Characterization and Pharmacological Evaluation of Sulfated Polysaccharides from Three Species of Mediterranean Brown Algae of the Genus Cystoseira. DARUJ Pharm. Sci. 2015, 23, 4-11. [CrossRef]

43. Sellimi, S.; Kadri, N.; Barragan-Montero, V.; Laouer, H.; Hajji, M.; Nasri, M. Fucans from a Tunisian Brown Seaweed Cystoseira Barbata: Structural Characteristics and Antioxidant Activity. Int. J. Biol. Macromol. 2014, 66, 281-288. [CrossRef]

44. Liu, J.; Wu, S.-Y.; Chen, L.; Li, Q.-J.; Shen, Y.-Z.; Jin, L.; Zhang, X.; Chen, P.-C.; Wu, M.-J.; Choi, J.; et al. Different Extraction Methods Bring about Distinct Physicochemical Properties and Antioxidant Activities of Sargassum fusiforme Fucoidans. Int. J. Biol. Macromol. 2019, 155, 1385-1392. [CrossRef]

45. Ptak, S.H.; Christensen, K.V.; Meichßner, R.; Fretté, X. Improving Fucoidan Yield from Fucus Brown Algae by Microwave Extraction. Chem. Eng. Trans. 2019, 74, 109-114. [CrossRef]

46. Hanjabam, M.D.; Kumar, A.; Tejpal, C.S.; Krishnamoorthy, E.; Kishore, P.; Ashok Kumar, K. Isolation of Crude Fucoidan from Sargassum Wightii Using Conventional and Ultra-Sonication Extraction Methods. Bioact. Carbohydr. Diet. Fibre 2019, $20,100200$. [CrossRef]

47. Kadam, S.U.; Donnell, C.P.O.; Rai, D.K.; Hossain, M.B.; Burgess, C.M.; Walsh, D.; Tiwari, B.K. Laminarin from Irish Brown Seaweeds Ascophyllum nodosum and Laminaria hyperborea. Mar. Drugs 2015, 13, 4270-4280. [CrossRef] [PubMed]

48. Schaeffer, D.J.; Krylov, V.S. Anti-HIV Activity of Extracts and Compounds from Algae and Cyanobacteria. Ecotoxicol. Environ. Saf. 2000, 45, 208-227. [CrossRef] [PubMed]

49. Haroun-Bouhedja, F.; Ellouali, M.; Sinquin, C.; Boisson-Vidal, C. Relationship between Sulfate Groups and Biological Activities of Fucans. Thromb. Res. 2000, 100, 453-459. [CrossRef]

50. Wang, J.; Zhang, J.; Zhao, B.; Wang, X.; Wu, Y.; Yao, J.A. Comparison Study on Microwave-Assisted Extraction of Potentilla anserina L. Polysaccharides with Conventional Method: Molecule Weight and Antioxidant Activities Evaluation. Carbohydr. Polym. 2010, 80, 84-93. [CrossRef]

51. Fletcher, H.R.; Biller, P.; Ross, A.B.; Adams, J.M.M. The Seasonal Variation of Fucoidan within Three Species of Brown Macroalgae. Algal Res. 2017, 22, 79-86. [CrossRef]

52. Imbs, T.I.; Skriptsova, A.V.; Zvyagintseva, T.N. Antioxidant Activity of Fucose-Containing Sulfated Polysaccharides Obtained from Fucus Evanescens by Different Extraction Methods. J. Appl. Phycol. 2015, 27, 545-553. [CrossRef]

53. Rodriguez-Jasso, R.M.; Mussatto, S.I.; Pastrana, L.; Aguilar, C.N.; Teixeira, J.A. Microwave-Assisted Extraction of Sulfated Polysaccharides (Fucoidan) from Brown Seaweed. Carbohydr. Polym. 2011, 86, 1137-1144. [CrossRef] 
54. Rodríguez-Jasso, R.M.; Mussatto, S.I.; Pastrana, L.; Aguilar, C.N.; Teixeira, J.A. Extraction of Sulfated Polysaccharides by Autohydrolysis of Brown Seaweed Fucus Vesiculosus. J. Appl. Phycol. 2013, 25, 31-39. [CrossRef]

55. Hentati, F.; Delattre, C.; Ursu, A.V.; Desbrières, J.; Le Cerf, D.; Gardarin, C.; Abdelkafi, S.; Michaud, P.; Pierre, G. Structural Characterization and Antioxidant Activity of Water-Soluble Polysaccharides from the Tunisian Brown Seaweed Cystoseira Compressa. Carbohydr. Polym. 2018, 198, 589-600. [CrossRef] [PubMed]

56. Ammar, H.H.; Hafsa, J.; Le Cerf, D.; Bouraoui, A.; Majdoub, H. Antioxidant and Gastroprotective Activities of Polysaccharides from the Tunisian Brown Algae (Cystoseira sedoides). J. Tunis. Chem. Soc. 2016, 18, 80-88.

57. Sahera, M.F.; Thani, S.M.; Salha, S.Y. Characterization of Sulphated Polysaccharide with Antiviral Activity from Marine Brown Alga Cystoseira Myrica Collected from Jazan Coasts, KSA. Int. J. PharmTech Res. 2015, 8, 198-203.

58. January, G.G.; Naidoo, R.K.; Kirby-McCullough, B.; Bauer, R. Assessing Methodologies for Fucoidan Extraction from South African Brown Algae. Algal Res. 2019, 40, 101517. [CrossRef]

59. Hamid, N.; Ma, Q.; Boulom, S.; Liu, T.; Zheng, Z.; Balbas, J.; Robertson, J. Seaweed Minor. Constituents; Tiwari, B.K., Troy, D.J., Eds.; Elsevier Inc.: Amsterdam, The Netherlands, 2015; ISBN 9780124199583.

60. Saravana, P.S.; Cho, Y.J.; Park, Y.B.; Woo, H.C.; Chun, B.S. Structural, Antioxidant, and Emulsifying Activities of Fucoidan from saccharina Japonica Using Pressurized Liquid Extraction. Carbohydr. Polym. 2016, 153, 518-525. [CrossRef] [PubMed]

61. Mak, W.W.F. Extraction, Characterization and Antioxidant Activity of Fucoidan from New Zealand Undaria Pinnatifida (Harvey) Suringar; Auckland University of Technology: Auckland, New Zealand, 2012.

62. Wang, C.Y.; Wu, T.C.; Hsieh, S.L.; Tsai, Y.H.; Yeh, C.W.; Huang, C.Y. Antioxidant Activity and Growth Inhibition of Human Colon Cancer Cells by Crude and Purified Fucoidan Preparations Extracted from Sargassum cristaefolium. J. Food Drug Anal. 2015, 23, 766-777. [CrossRef] [PubMed]

63. Wozniak, M.; Bell, T.; Dénes, Á.; Falshaw, R.; Itzhaki, R. Anti-HSV1 Activity of Brown Algal Polysaccharides and Possible Relevance to the Treatment of Alzheimer's Disease. Int. J. Biol. Macromol. 2015, 74, 530-540. [CrossRef]

64. Kadam, S.U.; Tiwari, B.K.; O'Connell, S.; O'Donnell, C.P. Effect of Ultrasound Pretreatment on the Extraction Kinetics of Bioactives from Brown Seaweed (Ascophyllum nodosum). Sep. Sci. Technol. 2015, 50, 670-675. [CrossRef]

65. Alboofetileh, M.; Rezaei, M.; Tabarsa, M.; You, S.G. Bioactivities of Nizamuddinia zanardinii Sulfated Polysaccharides Extracted by Enzyme, Ultrasound and Enzyme-Ultrasound Methods. J. Food Sci. Technol. 2019, 56, 1212-1220. [CrossRef]

66. Muhammad, A.I.; Xiang, Q.; Liao, X.; Liu, D.; Ding, T. Understanding the Impact of Nonthermal Plasma on Food Constituents and Microstructure-A Review. Food Bioprocess Technol. 2018, 11, 463-486. [CrossRef]

67. Wang, J.; Zhang, Q.; Zhang, Z.; Li, Z. Antioxidant Activity of Sulfated Polysaccharide Fractions Extracted from Laminaria japonica. Int. J. Biol. Macromol. 2008, 42, 127-132. [CrossRef] [PubMed]

68. Nishino, T.; Nagumo, T. The Sulfate-Content Dependence of the Anticoagulant Activity of a Fucan Sulfate from the Brown Seaweed Ecklonia kurome. Carbohydr. Res. 1991, 214, 193-197. [CrossRef]

69. Nishino, T.; Nagumo, T. Anticoagulant and Antithrombin Activities of Oversulfated Fucans. Carbohydr. Res. 1992, 229, 355-362. [CrossRef]

70. Cumashi, A.; Ushakova, N.A.; Preobrazhenskaya, M.E.; D'Incecco, A.; Piccoli, A.; Totani, L.; Tinari, N.; Morozevich, G.E.; Berman, A.E.; Bilan, M.I.; et al. A Comparative Study of the Anti-Inflammatory, Anticoagulant, Antiangiogenic, and Antiadhesive Activities of Nine Different Fucoidans from Brown Seaweeds. Glycobiology 2007, 17, 541-552. [CrossRef]

71. Bilan, M.I.; Grachev, A.A.; Shashkov, A.S.; Nifantiev, N.E.; Usov, A.I. Structure of a Fucoidan from the Brown Seaweed Fucus serratus L. Carbohydr. Res. 2006, 341, 238-245. [CrossRef]

72. Ale, M.T.; Maruyama, H.; Tamauchi, H.; Mikkelsen, J.D.; Meyer, A.S. Fucoidan from Sargassum sp. and Fucus vesiculosus Reduces Cell Viability of Lung Carcinoma and Melanoma Cells In Vitro and Activates Natural Killer Cells in Mice In Vivo. Int. J. Biol. Macromol. 2011, 49, 331-336. [CrossRef]

73. Foley, S.A.; Mulloy, B.; Tuohy, M.G. An Unfractionated Fucoidan from Ascophyllum nodosum: Extraction, Characterization, and Apoptotic Effects In Vitro. J. Nat. Prod. 2011, 74, 1851-1861. [CrossRef]

74. Ponce, N.M.A.; Pujol, C.A.; Damonte, E.B.; Flores, M.L.; Stortz, C.A. Fucoidans from the Brown Seaweed Adenocystis utricularis: Extraction Methods, Antiviral Activity and Structural Studies. Carbohydr. Res. 2003, 338, 153-165. [CrossRef]

75. Ale, M.T.; Mikkelsen, J.D.; Meyer, A.S. Designed Optimization of a Single-Step Extraction of Fucose-Containing Sulfated Polysaccharides from Sargassum sp. J. Appl. Phycol. 2011, 24, 715-723. [CrossRef]

76. Duarte, M.E.R.; Cardoso, M.A.; Noseda, M.D.; Cerezo, A.S. Structural Studies on Fucoidans from the Brown Seaweed Sargassum stenophyllum. Carbohydr. Res. 2001, 333, 281-293. [CrossRef]

77. Balboa, E.M.; Rivas, S.; Moure, A.; Domínguez, H.; Parajó, J.C. Simultaneous Extraction and Depolymerization of Fucoidan from Sargassum muticum in Aqueous Media. Mar. Drugs 2013, 11, 4612-4627. [CrossRef] [PubMed]

78. Kuznetsova, T.A.; Persiyanova, E.V.; Ermakova, S.P.; Khotimchenko, M.Y.; Besednova, N.N. The Sulfated Polysaccharides of Brown Algae and Products of Their Enzymatic Transformation as Potential Vaccine Adjuvants. Nat. Prod. Commun. 2018, 13, 1083-1095. [CrossRef]

79. Chaminda Lakmal, H.H.; Lee, J.-H.; Jeon, Y.-J. Enzyme-Assisted Extraction of a Marine Algal Polysaccharide, Fucoidan and Bioactivities. In Polysaccharides: Bioactivity and Biotechnology; Springer: Cham, Switzerland, 2015; pp. 1-2241. ISBN 9783319162980.

80. Yuan, Y.; Macquarrie, D.J. Microwave Assisted Step-by-Step Process for the Production of Fucoidan, Alginate Sodium, Sugars and Biochar from Ascophyllum nodosum through a Biorefinery Concept. Bioresour. Technol. 2015, 198, 819-827. [CrossRef] [PubMed] 
81. Alboofetileh, M.; Rezaei, M.; Tabarsa, M.; Rittà, M.; Donalisio, M.; Mariatti, F.; You, S.G.; Lembo, D.; Cravotto, G. Effect of Different Non-Conventional Extraction Methods on the Antibacterial and Antiviral Activity of Fucoidans Extracted from Nizamuddinia zanardinii. Int. J. Biol. Macromol. 2018, 124, 131-137. [CrossRef] [PubMed]

82. Fitton, J.H.; Stringer, D.N.; Karpiniec, S.S. Therapies from Fucoidan: An Update. Mar. Drugs 2015, 13, 5920-5946. [CrossRef]

83. Yuan, Y.; Macquarrie, D. Microwave Assisted Extraction of Sulfated Polysaccharides (Fucoidan) from Ascophyllum nodosum and Its Antioxidant Activity. Carbohydr. Polym. 2015, 129, 101-107. [CrossRef]

84. Van Weelden, G.; Bobi, M.; Okła, K.; van Weelden, W.J.; Romano, A.; Pijnenborg, J.M.A. Fucoidan Structure and Activity in Relation to Anti-Cancer Mechanisms. Mar. Drugs 2019, 17, 32. [CrossRef]

85. Barahona, T.; Chandía, N.P.; Encinas, M.V.; Matsuhiro, B.; Zúñiga, E.A. Antioxidant Capacity of Sulfated Polysaccharides from Seaweeds. A Kinetic Approach. Food Hydrocoll. 2011, 25, 529-535. [CrossRef] 